\title{
NEW DASCYLLIDAE.
}

BY CHARLES SCHAEFFER, BROOKLYN, N. Y.

\section{Lachnodactyla texana new species}

Piceous brown, antennae and legs paler, form of Ptilodactyla serricollis, but slightly more robust and the vestiture coarser. Head granulate-punctate; eyes large, separated by slightly less than their own width; antennae long and slender, joints four to ten each with a ramus, which is much longer than the joint to which it is attached. Prothorax twice as wide at base as long, sides compressed anteriorly, arcuately converging behind, hind angles acute and slightly reflexed; base bisinuate, denticulate; surface convex, feebly depressed behind, not very densely granulate-punctate. Scutellum moderate, sub-cordiform, not impressed at base but with four denticles. Elytra elongate, very little wider than the thorax at base, humeri rounded; punctate-striate, striae distinct, intervals finely and sparsely punctate. Apex of fifth ventral segment feebly emarginate. Length $6 \mathrm{~mm}$., width $2.75 \mathrm{~mm}$.

Esperanza Ranch, Brownsville, Texas, May 30, one male.

Differs from the Central American monticola by the head being granulate-punctate, scutellum without notch in front and with only two teeth on each side of base, the elytral striae distinct and finely but not rugosely punctate. Some of these characters separate it also from parviscutum.

Lachnodactyla arizonica new species.

Ferruginous-brown, closely resembling Ptilodactyla serricollis, but slightly more elongate. Head granulate-punctate; eyes rather small, widely separated by more than their own width; antennae slender, ramus of each joint as long, or very slightly longer, than the joint itself, last joint elongate-oval, slightly wider than the penultimate. Thorax at base twice as wide as long, bisinuate, denticulate; sides arcuately narrowing to apex; hind angles acute and feebly reflexed; surface convex and feebly depressed behind. Scutellum moderate, feebly cordate, median impression deep in front, but base without denticles on each side. Elytra elongate, slightly broader than the thorax at base, obsoletely punctate-striate, intervals flat, feebly rugose and finely punctate. Fifth ventral segment at apex feebly emarginate. Length $5 \mathrm{~mm}$., width $2.5 \mathrm{~mm}$. 
Huachuca Mts., Arizona, July 25, one male.

This species differs from texana by the smaller, more widely separated eyes, rami of antennal joints shorter, scutellum distinctly impressed in front and without denticles on the basal margin; this latter character and the granulatepunctate head separate it also from the two Central-American species.

The genus Lachnodactyla is closely related to Ptilodactyla, from which it is mainly distinguished by the last joint of maxillary palpi being very elongate and somewhat cultriform, and the third very small. The apical joint in the male is cleft on the inner side and spongy within, the insect apparently having the power of distending it at will as Mr. Champion suggests.

If the figure* of the maxillary palpus is correct, the two species above described differ also from the two Mexican species in the third joint being inserted at the sides near base of the last joint; the palpi having thus somewhat the form of the antennae of certain species of Lachnosterna.

Ora texana Champ. Biol. Cent. Am. Col., vol. III, pt. i, p. 604 (note).

This name is given to the Scirtes troberti of Dr. Horn, $†$ which, according to Mr. Champion, is distinct from the Mexican species.

Ora troberti Guér. Rev. et Mag. Zool. 1861, p. 545.

I have a specimen from Brownsville, Texas, which agrees with the description of this species and also nearly with the figure given in the Biologia, $\ddagger$ except that the elytra are brownish testaceous and not yellow and the third dark elytral stripe is narrowly confluent with the apical dot. I am unwilling to give the single specimen a new name on these variable differences, as it otherwise closely agrees in form, markings, etc., with the Mexican insect.

The genus $\mathrm{Ora}$ is closely allied to Scirtes from which it is separated by the posterior coxae being contiguous in front only, posteriorly separated by the intercoxal process; the thorax and elytra explanate and acutely margined.

Scirtes plagiatus new species.

Ovate, reddish testaceous, head, thorax and an oblique lateral stripe on each

* Biol. Cent. Am. vol. III, pt. 1, pl. 27, fig. 25a.

$\dagger$ Trans. Am. Ent. Soc., vol. VIII, p. 102, pl. 1, fig. 15.

$\ddagger$ Biol. Cent. Am. vol. III, pt. 1, p. 603, tab. xxvi, fig. 24 . 
elytron piceous. Head shining, finely and sparsely punctate and sparsely pubescent. First joint of antennae stout, second and third small, together as long as the fourth, fourth to tenth feebly decreasing in length, eleventh slightly longer than the tenth and rounded at apex. Thorax very strongly transverse; sides narrowing to apex, apical angles rounded, basal angles feebly so; base arcuate; surface finely and rather sparsely punctate and sparsely pubescent. Scutellum triangular, finely and sparsely punctate. Elytra more strongly punctate than the thorax, sparsely pubescent with fine, recumbent, pale hairs; color reddish testaceous, with an oblique, piceous vitta on each side, extending to about apical fourth, leaving apex and the suture narrowly pale. Body beneath sparsely pubescent; tibiae carinate. Length 3 mm., width $2 \mathrm{~mm}$.

Huachuca Mts., Arizona, June.

Readily distinguishable from all the described species by the coloration. 

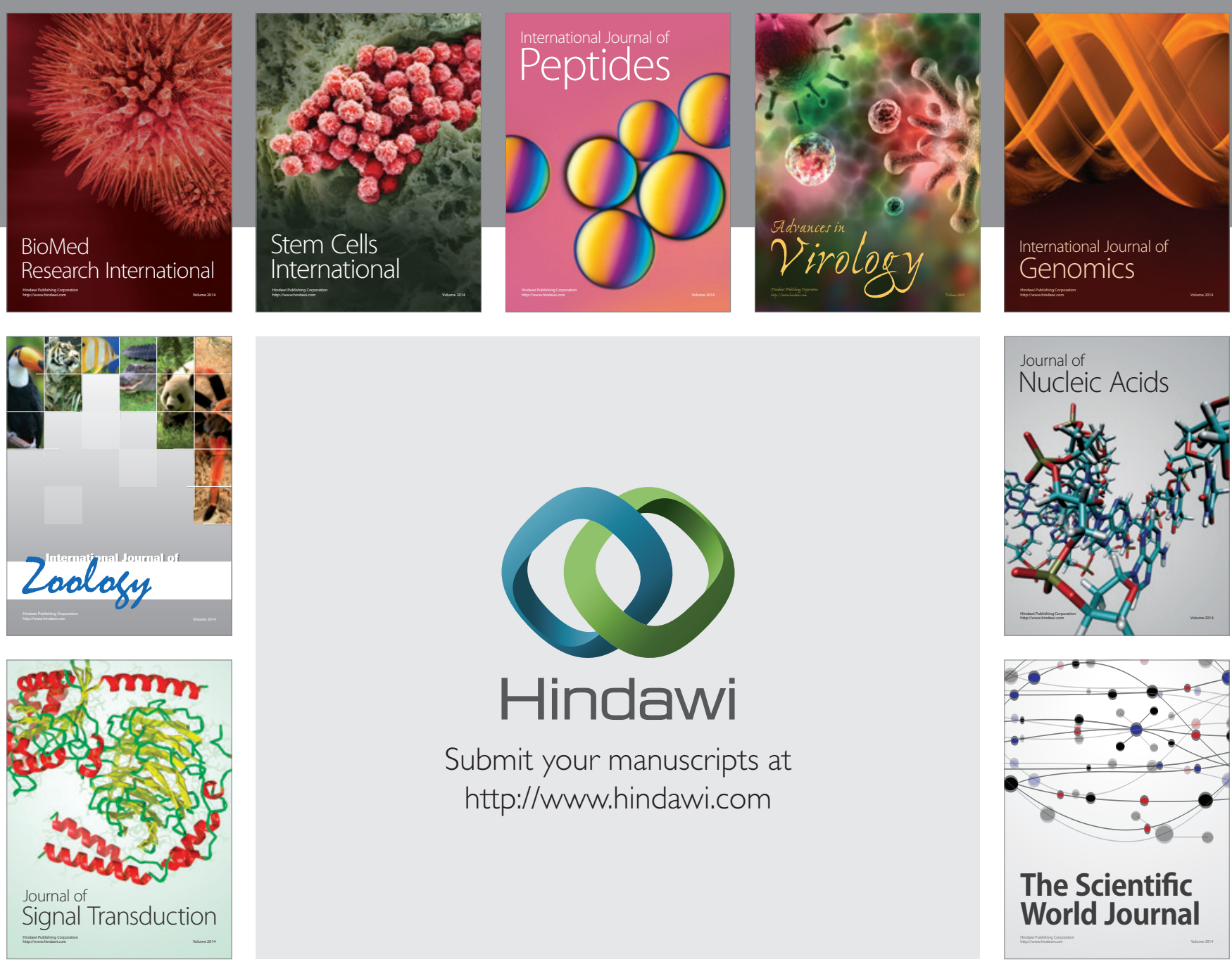

Submit your manuscripts at

http://www.hindawi.com
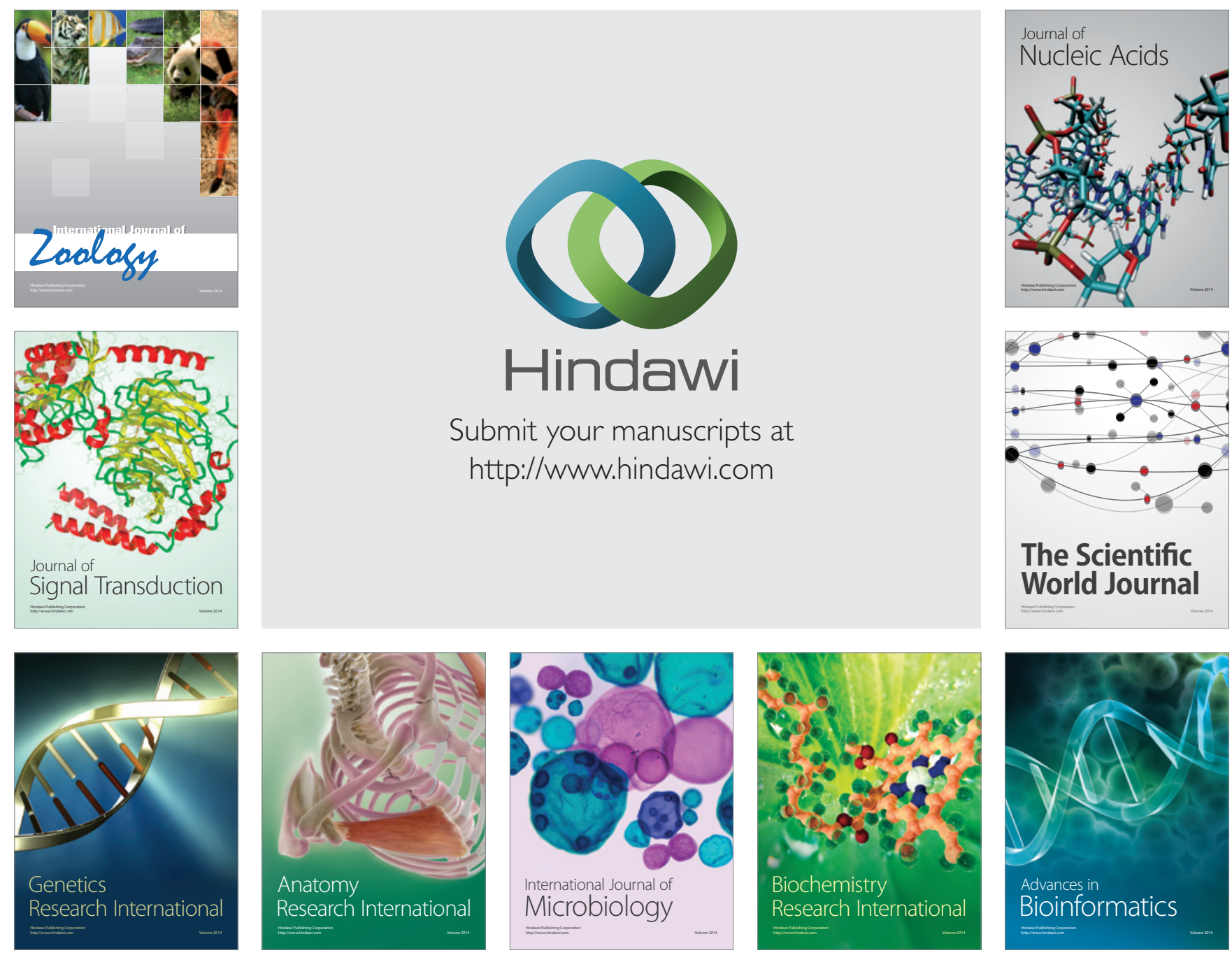

The Scientific World Journal
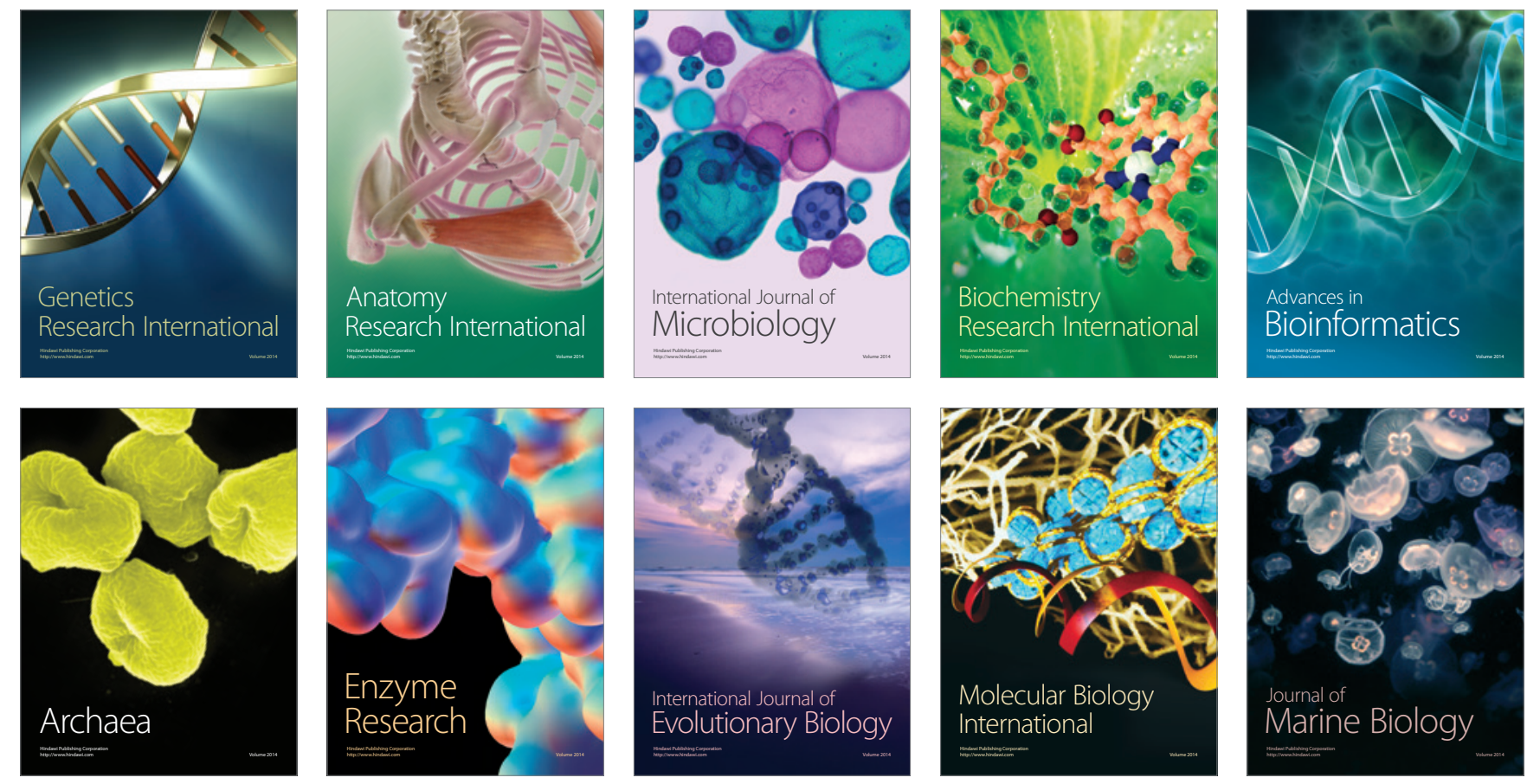